\title{
Inhibition of 5a-reductase of de novo Generation of Short Anti-oxidant Peptides
}

\author{
Sung-Gyu Lee ${ }^{*}$ and Hyun Kang ${ }^{\dagger ; *}$ \\ Department of Medical Laboratory Science, College of Health Science, Dankook University, \\ Cheonan-si, Chungnam 31116, Korea
}

This study aims to investigate the biological activities related to hair loss of short anti-oxidant peptides (DK peptides) $5 \alpha$-reductase inhibition and anti-oxidation. The series of DK peptides were generated amphipathic helical properties using leucines, lysines and tryptophan residues. Cell viability and free radical scavenging activities were performed using 3-(4, 5-dimethylthiazol-2-yl)-2, 5-diphenyl-tetrazolium bromide (MTT) and 2, 2-diphenyl-1-picrylhydrazyl (DPPH) assay, respectively. The DK peptides were investigated for inhibitory activity against $5 \alpha$-reductase. Antioxidant activities were determined by means of, 2, 2-diphenyl-1-picrylhydrazyl (DPPH) assays. All peptides could inhibit $5 \alpha$-reductase in lipopolysaccharide-stimulated macrophage. In conclusion, DK peptides was suggested as the most attractive ingredients for improving hair loss, because of the high inhibitory against $5 \alpha$-reductase inhibition.

Key Words: $5 \alpha$-reductase, Anti-oxidant peptides, Hair loss

\section{INTRODUCTION}

Androgenetic alopecia is a significant issue that can occurs in all ages. Generally, it is caused hair loss, which depends on the presence of the androgenic hormones, including testosterone and dihydrotestosterone (Stough et al., 2005; Dawber 1987; Cotsarelis and Millar, 2001). In the human body, dihydrotestosterone is an enzymatic product converted from testosterone by the role of $5 \alpha$-reductase. Since dihydrotestosterone is more active than testosterone, blocking the conversion of testosterone to DHT would reduce the androgenic effect. Thus, anti-androgenic drugs, which inhibit $5 \alpha$-reductase or bind between dihydrotestosterone and androgen receptor, may be useful for protection from androgenetic alopecia
(Matsuda et al., 2001). The hair follicle is a cutaneous organ that remodels itself during cyclical periods of active hair growth (anagen), apoptosis-driven involution (catagen), hair shedding (exogen), and relative rest (telogen) (Ahn et al., 2001). Beside the androgenic hormones, the miniaturization of hair follicle might be explained by a shorter anagen cycle (Whiting, 2001). The hair follicle size and the duration of anagen phase indicate the length and the size of hair shaft, respectively (Cotsarelis and Millar, 2001). The normal duration of anagen is around $2 \sim 6$ years on average, and then it will turn to a short transitory period of catagen, in which the follicle will undergo apoptosis (Otberg et al., 2001). Free radicals, which are highly reactive molecules with unpaired electrons that can directly damage various cellular components, might be another factor affecting the hair loss in

Received: July 11, 2018 / Revised: September 28, 2018 / Accepted: October 1, 2018

*Professor.

${ }^{\dagger}$ Corresponding author: Hyun Kang. Department of Medical Laboratory Science, College of Health Science, Dankook University, Cheonan-si, Chungnam, 31116 , Korea.

Tel: +82-41-550-3015, Fax: +82-41-559-7934, e-mail: hkang@dankook.ac.kr

(C) The Korean Society for Biomedical Laboratory Sciences. All rights reserved.

(C) This is an Open Access article distributed under the terms of the Creative Commons Attribution Non-Commercial License (http://creativecommons.org/licenses/by-nc/3.0/) which permits unrestricted non-commercial use, distribution, and reproduction in any medium, provided the original work is properly cited. 
androgenetic alopecia. Since the oxidation process leads to progressive damage of cellular structures, the ageing phenotype of hair manifests as a decrease in hair production. It has been reported that lipid peroxides on hair follicles led to the early onset of the catagen in murine hair cycles (Wood et al., 2009). Therefore, antioxidant compounds might be used to prolong the anagen phase and reduce the hair loss. The series of DK peptides were generated amphipathic helical properties were conferred by using leucines, lysines and tryptophan residues were positioned at the critical amphipathic interface between the hydrophilic ending side and the hydrophobic starting side (Table 1).

\section{MATERIALS AND METHODS}

The chemically synthesized model peptides were purchased as dry powders from the peptide manufacturer company A\&PEP(Oksan, Korea). RAW 264.7 cells were cultured at $37^{\circ} \mathrm{C}$ in $5 \% \mathrm{CO}_{2}$ in DMEM (Invitrogen, Carlsbad, CA, USA) supplemented with 5\% FBS (Hyclone, Logan, UT, USA) and antibiotics (Invitrogen). For viability assay, 3-(4, 5-dimethylthiazol-2-yl)-2, 5-diphenyl-tetrazolium bromide (MTT, Sigma-Aldrich, St. Louis, MO, USA) assay was used as described previously. Briefly, RAW 264.7 cells were plated onto 96 well plates and exposed to DK peptides. MTT was added to each well then incubated for additional $2 \mathrm{~h}$ in the dark at $37^{\circ} \mathrm{C}$. The medium was then aspirated from the wells and the blue formazan product obtained was dissolved in DMSO. The plates were analyzed at $570 \mathrm{~nm}$ using a microplate reader (Tecan Trading AG, Switzerland). Each experiment was conducted in triplicate. Cell viability (\%) was calculated as the ratio of the absorbance of sample to that of the non-treated sample, expressed as a percentage. In all other experiments, the cells were pre-treated with DK peptides with controls at indicated concentrations $(10,50$, and $100 \mu \mathrm{g} / \mathrm{mL})$ for $1 \mathrm{~h}$ before the addition of LPS $(100 \mathrm{ng} / \mathrm{mL}$, Sigma-Aldrich, St Louis, MO, USA) in serum free DMEM. An equal volume of sterile water was added to all control treatments. The radical scavenging activity of DK peptides was measured using a stable radical 2, 2-diphenyl-1-picrylhydrazyl (DPPH, Sigma-Aldrich, St. Louis, MO, USA). The scavenging effects were evaluated by employing a reaction
Table 1. Amino acid sequence of DK peptides

\begin{tabular}{ll}
\hline \hline Peptides & \multicolumn{1}{c}{ Amino acid sequence } \\
\hline DK-1 & KWLLRKLRKWL \\
DK-2 & KRLLRKLLKLL \\
DK-1-1 & KWLLWK \\
DK-1-2 & KWLLK \\
DK-1-3 & KWLWK \\
DK-2-1 & KLLKLKL \\
DK-2-2 & KLKLL \\
DK-2-3 & KLLKK \\
\hline
\end{tabular}

mixture constituted with aliquots of the DK peptides and a DPPH methanolic solution as described previously (Nanjo et al., 1996). Briefly, a sample solution of $60 \mu \mathrm{L}$ of each DK peptides, was added to $60 \mu \mathrm{L}$ of DPPH $(60 \mu \mathrm{M})$ in methanol. After mixing vigorously for $10 \mathrm{~s}$, the mixture was then transferred into a $100 \mu \mathrm{L}$ Teflon capillary tube and the scavenging activity of each sample on DPPH radical was measured using a JES-FA ESR spectrometer (Jeol Ltd, Tokyo, Japan). A spin adduct was measured on an ESR spectrometer exactly after $2 \mathrm{~min}$. Experimental conditions were as follows: central field, 3,475 G; modulation frequency, 100 $\mathrm{kHz}$; modulation amplitude, $2 \mathrm{G}$; microwave power, $5 \mathrm{~mW}$; gain, $6.3 \times 10^{5}$, and temperature, $298 \mathrm{~K}$. Production of NO was assayed by measuring the levels of nitrite in the culture supernatant using colorimetric assay with Griess reagent (Green et al, 1982). Briefly, RAW 264.7 cells $\left(2 \times 10^{5}\right.$ cells/ $\mathrm{mL}$ ) were seeded in 6-well plates in $500 \mu \mathrm{L}$ complete culture medium and treated with the DK peptides at indicated concentrations $(10,50$ and $100 \mu \mathrm{g} / \mathrm{mL})$ for $1 \mathrm{~h}$ prior to stimulation with LPS (100 ng/ mL) for $2 \mathrm{~h}$. Culture supernatant $(50 \mu \mathrm{L})$ was reacted with an equal volume of Griess reagent ( $0.1 \%$ naphthylethylenediamine and $1 \%$ sulfanilamide in $5 \%$ $\mathrm{H}_{3} \mathrm{PO}_{4}$ ) in 96-well plates at room temperature in the dark. Nitrite concentrations were determined by using standard solutions of sodium nitrite prepared in the culture medium. The absorbance was determined at $540 \mathrm{~nm}$ using a microplate reader (Tecan). RAW 264.7 cells $\left(1 \times 10^{5}\right.$ cells/well) were cultured in 96 well plates and treated with the DK peptides at the indicated concentrations for $1 \mathrm{~h}$ and stimulated with LPS (100 ng/mL). At $4 \mathrm{~h}$ post LPS treatment, the cells 
were collected and the supernatants were evaluated for $5 \alpha-$ reductase enzyme contents using a murine $5 \alpha$-reductase ELISA kit from BD Biosciences, respectively (San Jose, CA, USA) according to the manufacturer's instructions. All data are represented as the mean \pm S.E.M of at least three independent experiments. Statistical analyses were performed using SAS statistical software (SAS Institute, Cray, $\mathrm{NC}$, USA) using one-way analysis of variance, followed by Dunnett's multiple range tests. $P<0.05$ was considered statistically significant.

\section{RESULTS}

Amino acid sequences of the tested DK peptides and their structural parameters calculated from the sequences are summarized in Fig. 1. As shown in Fig. 2, DK peptides showed significant DPPH radical scavenging activity in a concentration-dependent manner. The maximum scavenging activity was observed at $100 \mu \mathrm{g} / \mathrm{mL}$ of concentration $(P<$ 0.001). However, DK peptides at concentration of 10 and $50 \mu \mathrm{g} / \mathrm{mL}$ also showed significant scavenging of DPPH radicals $(P<0.05$ and $P<0.01$ at 10 and $50 \mu \mathrm{g} / \mathrm{mL}$, respectively). The concentration needed for $50 \%$ inhibition of DPPH radical by DK-1 and DK-2 $(10 \mu \mathrm{g} / \mathrm{mL})$ were 45.64 $\pm 1.64 \mu \mathrm{g} / \mathrm{mL}$ and $46.24 \pm 1.87 \mu \mathrm{g} / \mathrm{mL}$. Oxidation process is another pathway related to hair loss since free radicals could damage the hair follicle cellular structures and lead to a decrease in hair production (Wood et al., 2009). There are several methods to investigate the antioxidant activity of natural compounds, including DPPH assay. However, the most relevant method related to hair loss was oxidation assay since it has been reported that oxidation on hair follicles led to the early onset of the catagen which would lead to the hair loss (Naito et al., 2008). As shown in Fig. 3, treatment with LPS $(100 \mathrm{ng} / \mathrm{mL})$ with or without DK-1 and DK-2 peptides at various concentrations $(10 \sim 100 \mu \mathrm{g} / \mathrm{mL})$ did not affect the overall cell viability nor did they exhibit any cytotoxicity on RAW 264.7 cells. NO is one of the important inflammatory mediators produced by activated microglia. To study the effect of DK peptides on LPS-stimulated NO release, RAW 264.7 cells were treated with various concentrations of DK-peptides $(10,50$ and $100 \mu \mathrm{g} / \mathrm{mL})$ for $30 \mathrm{~min}$ prior to

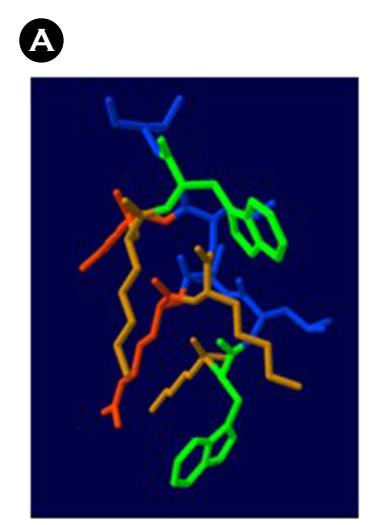

\section{B}
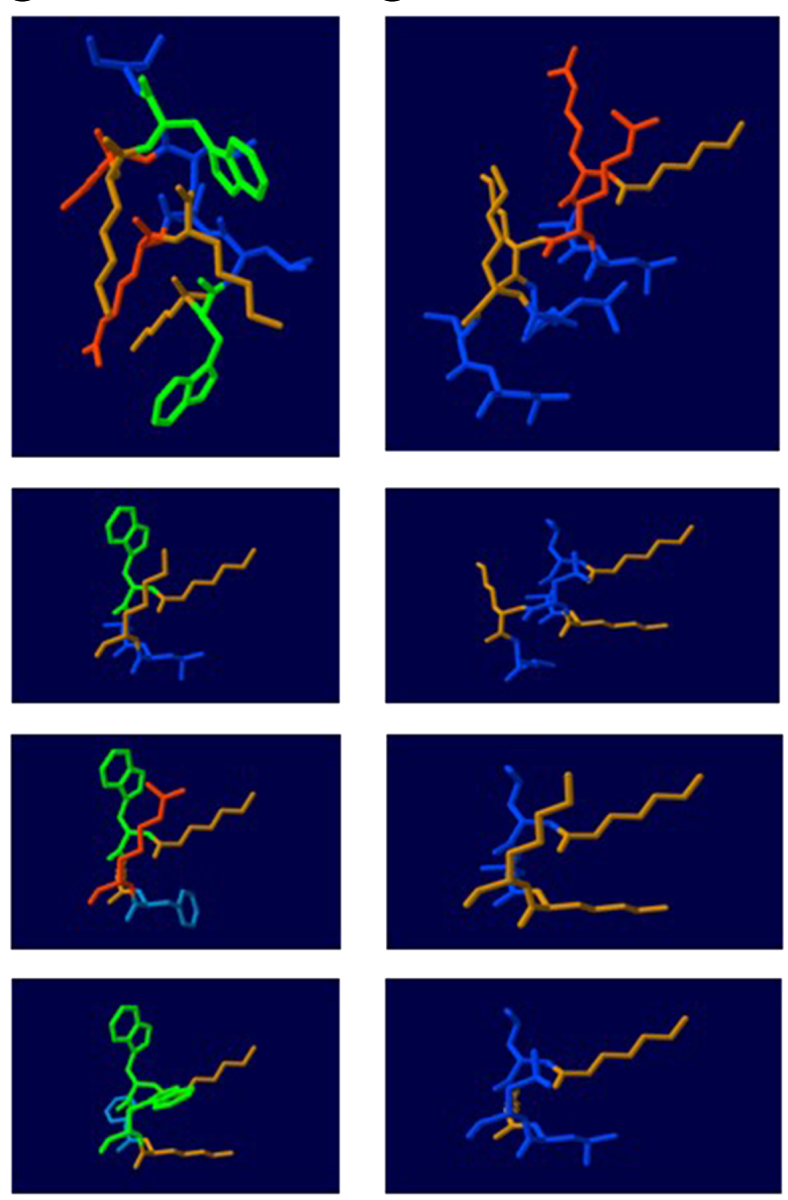

Fig. 1. 3D model of structures of DK-peptides, (A) DK-1, left upper panel; DK-1-1, left middle panel; DK-1-2, left second middle panel; DK-1-3, left lower panel, (B) DK-2 (right upper panel), DK-2-1, left middle panel; DK-2-2, left second middle panel; DK-2-3, left lower panel.

LPS (100 ng/mL) stimulation for $4 \mathrm{~h}$. NO production by LPS-activated cells was found to be significantly inhibited by DK-peptides in a concentration-dependent manner (Fig. 4). As shown in Fig. 5, 5 $\alpha$-reductase levels were increased significantly after LPS treatment $(1 \mu \mathrm{g} / \mathrm{mL})$ when compared to those in untreated cells $(P<0.001)$. However, DK-peptides $(10,50$ and $100 \mu \mathrm{g} / \mathrm{mL})$ significantly inhibited these $5 \alpha$ reductase actibities (Fig. 5) in a concentration-dependent manner in LPS-stimulated RAW 264.7 cells $(P<0.05$ at 10 $\mu \mathrm{g} / \mathrm{mL}, P<0.01$ at $50 \mu \mathrm{g} / \mathrm{mL}$ and $P<0.001$ at $100 \mu \mathrm{g} / \mathrm{mL}$, respectively). The presence of dihydrotestosterone, which is converted from testosterone by the role of 5a-reductase, 


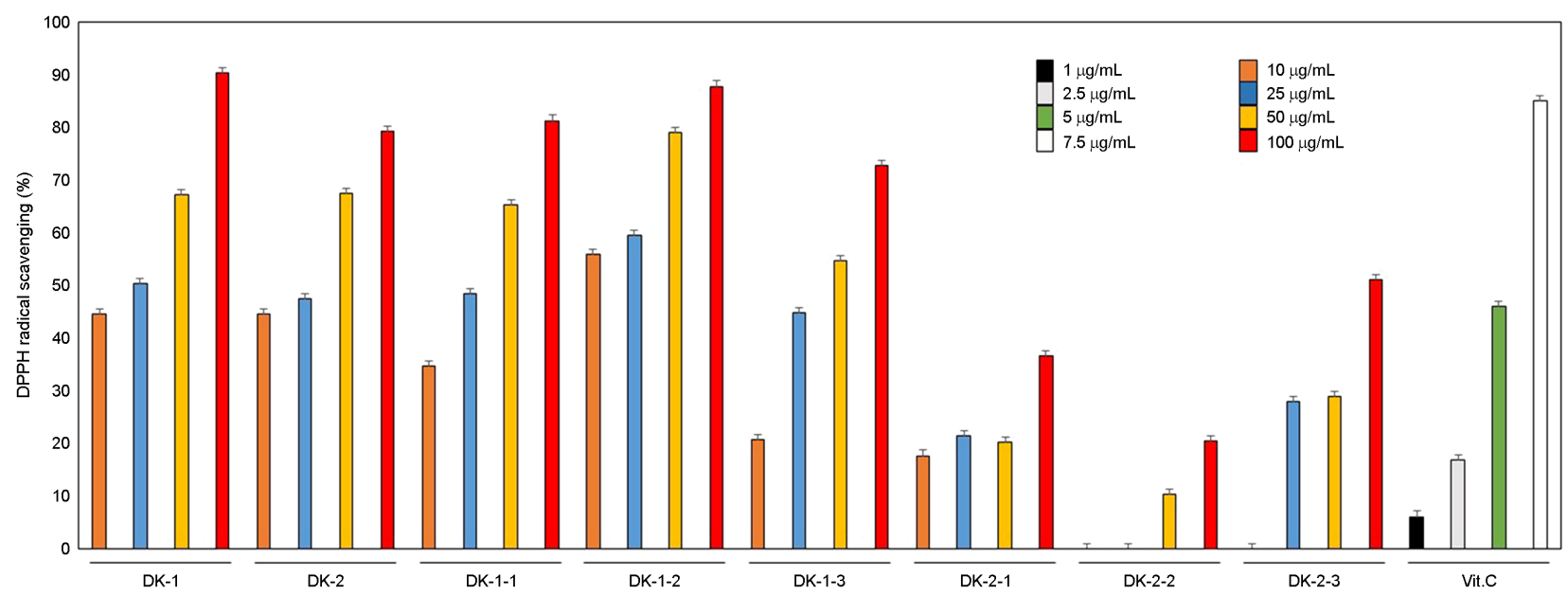

Fig. 2. Effects of DK-peptide on DPPH radical scavenging activity.

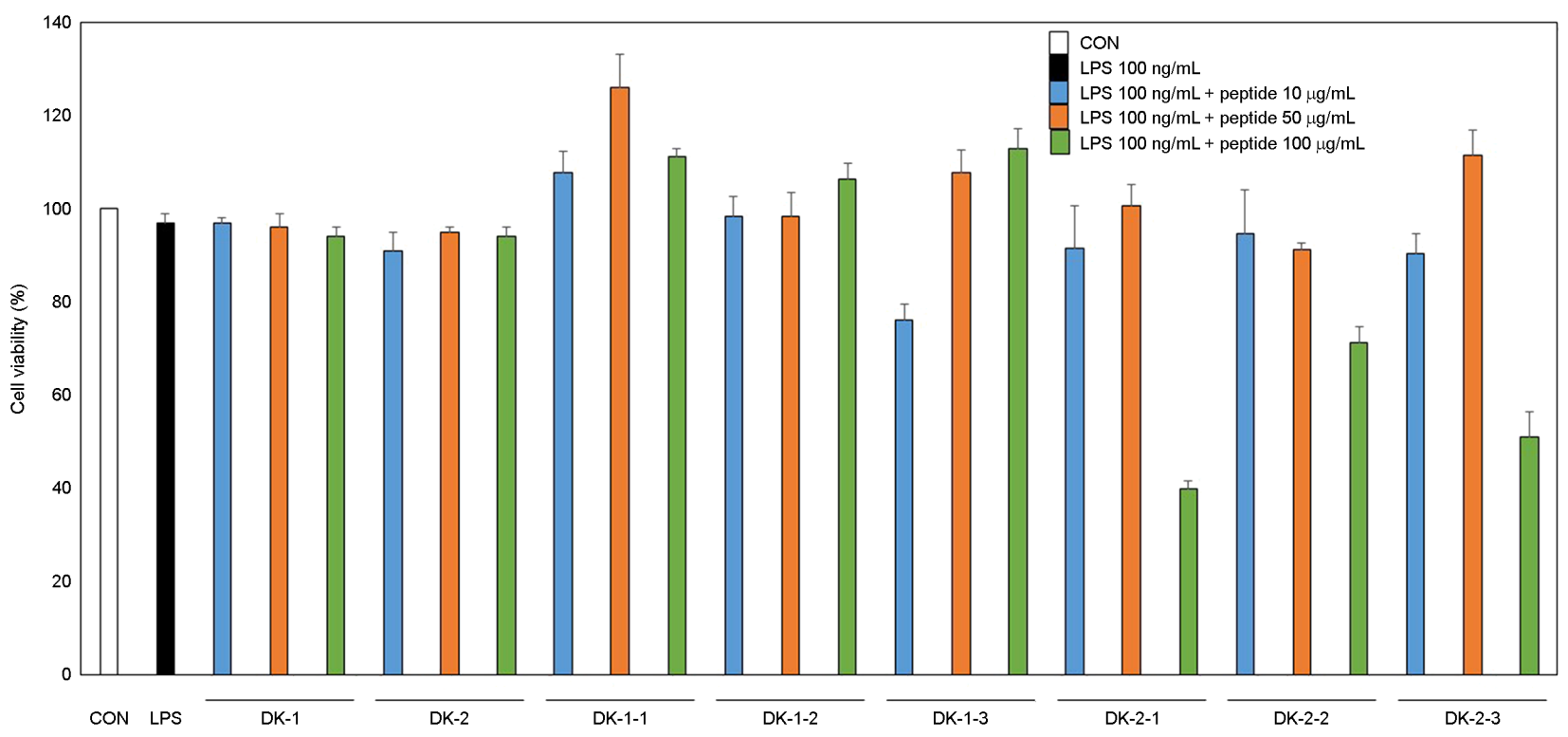

Fig. 3. Effects of DK-peptide on the viability of RAW 264.7 microglial cells. Cell viability in combination extract of DK-peptide treated cells was determined using MTT assay. The results are displayed in percentage of control samples.

is related to aberrant of hair follicle cycling, miniaturization of hair follicles, and finally hair loss. Therefore, the compounds that could inhibit $5 \alpha$-reductase would be useful for anti-hair loss.

\section{DISCUSSION}

To produce new hairs, existing follicles perpetually un- dergoes through three stages: growth (anagen), involution (catagen), and rest (telogen). Determining the molecular signals that orchestrate the follicle's transit between these stages is one of the key challenges of hair research. Numerous growth factors and growth factor receptors are critical for normal hair follicle development and cycling, but no single growth factor appears to exert ultimate control over these processes (Paus and Cotsarelis, 1999). Alopecia is 


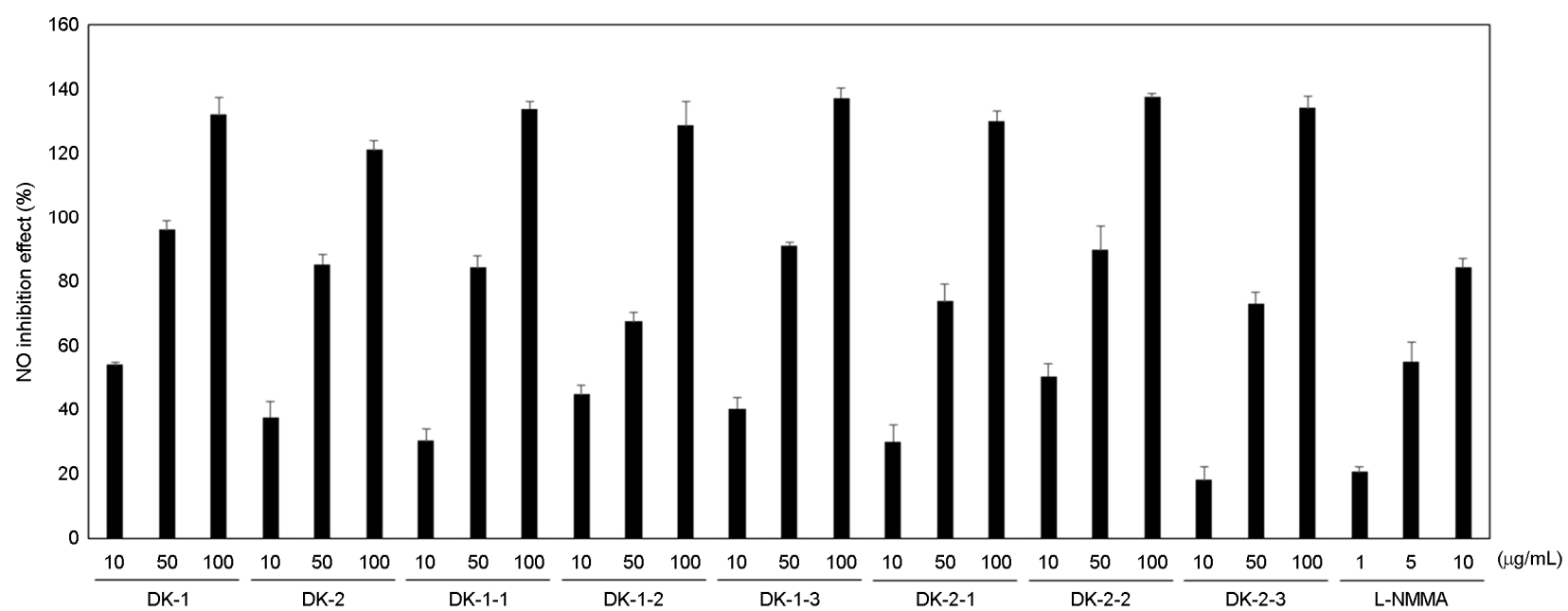

Fig. 4. Effects of DK-peptide on NO Production in LPS-stimulated RAW 264.7 microglial cells. RAW 264.7 cells were treated with DKpeptide with or without LPS $(100 \mathrm{ng} / \mathrm{mL})$ for $24 \mathrm{~h}$. The nitrite in the culture supernatant was evaluated using Griess reagent. L-NMMA; N-monomethyl-L-arginine.

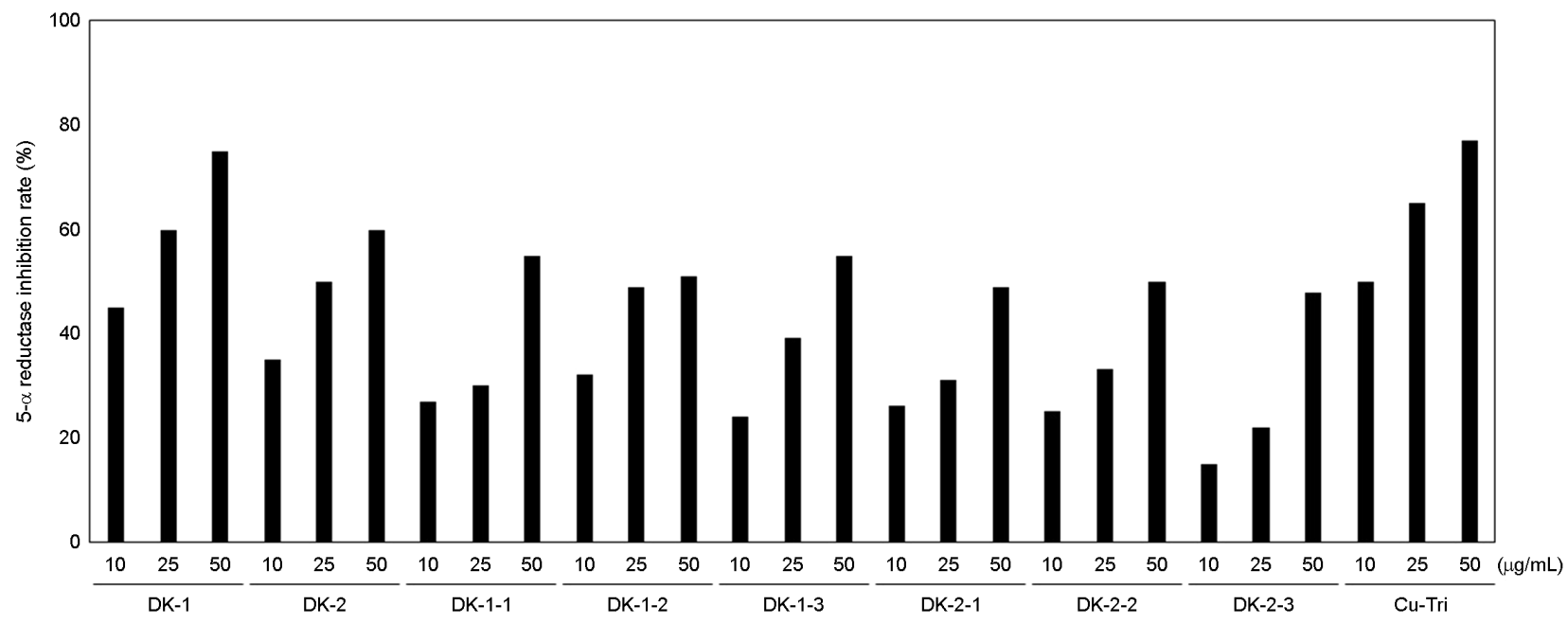

Fig. 5. Effects of DK-peptide on 5 $\alpha$-reductase inhibition activity.

defined as abnormal hair loss and is mainly caused by genetic factors, immune disorders and aging. In the United States, a research study among patients with diagnosed alopecia shows that above $70 \%$ of the patients have inflammatory diseases like atopy and contact dermatitis and mental health problems are seen in above $25 \%$ (Huang et al., 2013). Also, Alopecia is strongly related to an autoimmune disease. Alopecia' agonist effect can decreased fibroblast follicle cell growth and renewal, but antagonist effects can increased dihydrotesto- sterone (Dmytriw et al., 2015). 5 $\alpha$-reductase converts testosterone to dihydrotestosterone, which has a higher affinity for androgen receptors than testosterone and induces the expression of genes related to minimizing follicles, thus stimulating hair loss (Yim et al., 2014). A treatment for alopecia should prevent hair loss and promote hair growth. $5 \alpha$-reductase inhibitors and hair growth agents has been shown to improve the androgenetic alopecia (Amory et al., 2007). Alopecia may be treated by hair transplantation, but, 
hair transplantation is expensive, oral medicines have side effects such as hepatotoxicity, and oriental medicines are not clearly effective in improving hair growth (Traish et al., 2014). Identifying alternative treatments especially peptides that exhibit relatively low toxicity compared with synthetic drugs is therefore a dynamic area of research and development. All the peptides were designed to be perfectly amphipathic when folded into $\alpha$-helical structures, by converging the hydrophobic leucines into one side and the cationic lysines into the other side of the helical axis. The triptophan residues were always positioned at the critical amphipathic interface between the hydrophilic ending side and the hydrophobic starting side, in the helical wheel projection. In addition, the $5 \alpha$-reductase inhibitory activity of DK peptides was firstly described in the present study. The results noted that, among eight DK peptides, DK-1 and DK 1-3 possessed the significantly highest $5 \alpha$-reductase inhibition. Beside the role of $5 \alpha$-reductase and DHT, several cytokines are also related to the hair loss. IL-6 is one of the cytokines which has been more upregulated in balding dermal papilla cells (Kwak et al., 2012). In addition, IL-6 has been reported to inhibit the hair shaft elongation and suppressed proliferation of matrix human hair follicles cells and finally lead to the hair loss (Kwak et al., 2012). DK peptides that perhaps inhibit the IL-6 secretion might have several health benefits other than anti-hair loss.

\section{ACKNOWLEDGEMENTS}

This research was supported by the Ministry of Trade, Industry \& Energy (MOTIE), Korea Institute for Advancement of Technology (KIAT) through the encouragement program for the industries of economic cooperation region.

\section{CONFLICT OF INTEREST}

The authors declare that there is no conflict of interests regarding the publication this article.

\section{REFERENCES}

Ahn SY, Pi LQ, Hwang ST, Lee WS. Effect of IGF-I on hair growth is related to the anti-apoptotic effect of IGF-I and up-regulation of PDGF-A and PDGF-B. Annals of Dermatology. 2012. 24:
26-31.

Amory JK, Wang C, Swerdloff RS, Anawalt BD, Matsumoto AM, Bremner WJ, Walker SE, Haberer LJ, Clark RV. The effect of 5alpha-reductase inhibition with dutasteride and finasteride on semen parameters and serum hormones in healthy men. $\mathrm{J}$ Clin Endocrinol Metab. 2007. 92: 1659-1665.

Cotsarelis G, Millar SE. Towards a molecular understanding of hair loss and its treatment. Trends in Molecular Medicine. 2001. 7: 293-301.

Dawber RPR. Aetiology and pathophysiology of hair loss. Dermatology. 1987. 175: 23-28.

Dmytriw AA, Morzycki W, Green PJ. Prevention of Alopecia in Medical and Interventional Chemotherapy Patients. J Cutan Med Surg. 2015. 19: 11-16.

Green LC, Wagner DA, Glogowski J, Skipper PL, Wishnok JS, Tannenbaum SR. Analysis of nitrate, nitrite, and [15N] nitrite in biological fluids. Analytical Biochemistry. 1982. 126: 131 $-138$

Huang KP, Mullangi S, Guo Y, Qureshi AA. Autoimmune, atopic, and mental health comorbid conditions associated with alopecia areata in the United States. JAMA Dermatol. 2013. 149: 789 -794 .

Nanjo F, Goto K, Seto R, Suzuki M. Scavenging effects of tea catechins and their derivatives on 1,1-diphenyl-2-picrylhydrazyl radical. Free Radical Biology And Medicine. 1996. 21: 895 -902 .

Kwack MH, Ahn JS, Kim MK, Kim JC, Sung, YK. Dihydrotestosterone-inducible IL-6 inhibits elongation of human hair shafts by suppressing matrix cell proliferation and promotes regression of hair follicles in mice. Journal of Investigative Dermatology. 2012. 132: 43-49.

Matsuda H, Yamazaki M, Matsuo K, Asanuma Y, Kubo M. Antiandrogenic Activity of Myricae Cortex-Isolation of Active Constituents from Bark of Myrica rubra. Biological and Pharmaceutical Bulletin. 2001. 24: 259-263.

Naito A, Midorikawa T, Yoshino T, Ohdera M. Lipid peroxides induce early onset of catagen phase in murine hair cycles. International Journal of Molecular Medicine. 2008. 22: 725.

Otberg N, Finner AM, Shapiro J. Androgenetic alopecia. Endocrinology Metabolism Clinics of North America. 2007. 36: 379 -398 .

Paus R, Cotsarelis G. The biology of hair follicles. N Engl J Med 1999. 341: 491-497.

Stough D, Stenn K, Haber R, Parsley WM, Vogel JE, Whiting DA. 
Washenik, K. Psychological effect, pathophysiology, and management of androgenetic alopecia in men. Mayo Clinic Proceedings. 2005. 80: 1316-1322.

Traish AM, Hassani J, Guay AT, Zitzmann M, Hansen ML. Adverse side effects of 5alpha-reductase inhibitors therapy: persistent diminished libido and erectile dysfunction and depression in a subset of patients. J Sex Med. 2011. 8: 872-884.

Yim E, Nole KL, Tosti A. 5alpha-Reductase inhibitors in androgenetic alopecia. Curr Opin Endocrinol Diabetes Obes. 2014. 21:493-498.

Whiting DA. Possible mechanisms of miniaturization during androgenetic alopecia or pattern hair loss. Journal of the American
Academy of Dermatology. 2001. 45: 81-86.

Wood JM, Decker H, Hartmann H, Chavan B, Rokos H, Spencer JD, Hasse S, Thornton MJ, Shalbaf M, Paus R. Senile hair graying: $\mathrm{H}_{2} \mathrm{O}_{2}$-mediated oxidative stress affects human hair color by blunting methionine sulfoxide repair. The FASEB Journal. 2009. 23: 2065-2075.

https://doi.org/10.15616/BSL.2018.24.3.263

Cite this article as: Lee $\mathrm{SG}$, Kang $\mathrm{H}$. Inhibition of $5 \alpha-$ reductase of de novo Generation of Short Anti-oxidant Peptides. Biomedical Science Letters. 2018. 24: 263-269. 